\title{
Identification of Microsatellite Markers and Their Application to Population Genetics of Venturia inaequalis
}

\author{
Isabel Tenzer, Stefania degli Ivanissevich, Michele Morgante, and Cesare Gessler
}

First and fourth authors: Phytomedicine/Pathology, Institute of Plant Sciences, Swiss Federal Institute of Technology, Universitätstrasse 2, 8092 Zürich, Switzerland; and second and third authors: Dipartimento di Produzione Vegetale e Tecnologie Agrarie, Università di Udine, Via delle Scienze 208, 33100 Udine, Italy.

Current address of M. Morgante: DuPont Agricultural Biotechnology, Delaware Technology Park, Suite 200, 1 Innovation Way, P.O. Box 6104, Newark, DE 19714-6104.

Accepted for publication 29 May 1999.

\begin{abstract}
Tenzer, I., degli Ivanissevich, S., Morgante, M., and Gessler, C. 1999. Identification of microsatellite markers and their application to population genetics of Venturia inaequalis. Phytopathology 89:748-753.

Microsatellite markers of Venturia inaequalis were developed using genomic libraries of $V$. inaequalis enriched for the simple sequence repeats $(\mathrm{TC})_{n}$ and (AAC) $)_{n}$. Seven markers, three with (TC) $)_{n}$ repeats and four with $(\mathrm{AAC})_{n}$ repeats, were selected for the analyses of 350 isolates of $\mathrm{V}$. inaequalis collected from 11 sites in Europe. Polymorphism in the (TC) repeats was higher than in the (AAC) $)_{n}$ repeats. Nei's expected genetic diversity $\left(\mathrm{H}_{\mathrm{E}}\right)$ varied between 0.52 and 0.96 for the microsatellites containing (TC) ${ }_{n}$ stretches and between 0.09 and 0.36 for the microsatellites
\end{abstract}

ABSTRACT

Apple scab, caused by the ascomycete Venturia inaequalis (Cooke) G. Wint., is the most important disease found in apple (Malus domestica) cultivation. Epidemics begin in spring when ascospores are released and infect young emerging apple leaves. Conidia are then produced from these infections and continue the epidemic by infecting leaves and fruits. Although ascospores and conidia are primarily spread by rain splashing on infected leaves $(2,34)$, wind distribution of infected leaves and airborne ascospores can add to the migration of the fungus (10). V. inaequalis is normally managed using a fungicide spray program. However, development of scabresistant apple cultivars carrying the $V f$ resistance gene could be a step toward a more ecological-based production system for producing high quality apples with reduced fungicide input $(3,10)$. Although the $V f$ resistance was considered highly durable (1), scab isolates capable of infecting particular $V f$-resistant cultivars were found in Ahrensburg, Germany, in 1984 (19); in Kent, Great Britain, in 1994 (22); and in Wilheminadorp, the Netherlands, in 1997 (8).

To study the population genetics of $\mathrm{V}$. inaequalis in Europe, $4 \mathrm{~V}$. inaequalis populations collected in Switzerland (1993) and 11 populations collected in five European countries (1995) were analyzed using random amplified polymorphic DNA (RAPD) markers as well as polymerase chain reaction-restriction fragment length polymorphism (PCR-RFLP) $(29,30)$. The main findings were that Nei's genetic diversity (15) within populations was very high, whereas differentiation among populations was low to moderate. The Alps were not a barrier sufficient to clearly separate populations from south and north. The most important factor in reducing gene flow seemed to be the geographic distance.

Corresponding author: C. Gessler; E-mail address: Cesare.Gessler@ipw.agrl.ethz.ch

Publication no. P-1999-0708-01R

(C) 1999 The American Phytopathological Society containing (AAC) $)_{n}$ stretches. Within-population diversity $\left(\mathrm{H}_{\mathrm{S}}\right)$ was very high with values ranging from 0.28 to 0.49 , whereas differentiation among all European populations $\left(\mathrm{G}_{\mathrm{ST}}\right)$ was low with an average of 0.07 . In the population from Ahrensburg (northern Germany) where isolates were mainly collected from apple varieties carrying the $V f$ gene, usually resistant to $V$. inaequalis, we showed a bottleneck effect with reduced diversity and loss of alleles. The great advantages of microsatellite markers over random amplified polymorphic DNA and polymerase chain reaction-restriction fragment length polymorphism markers are their high specificity, high polymorphism, good reproducibility, and unambiguous scorability.

Additional keywords: apple scab, simple sequence repeat.
To better understand the population biology of $V$. inaequalis, we were interested in developing microsatellite (simple sequence repeat [SSR]) markers as more informative markers. Microsatellite markers have several advantages over RFLPs or RAPDs: they are technically simple to be handled, small amounts of DNA are needed for PCR amplification, they are unambiguously scorable, and results are highly reproducible. In addition, microsatellite markers are codominant and, therefore, widely used in genome mapping (4, $12,33)$ as well as in population genetics $(5,17,20,21)$. SSRs are stretches of tandemly repeated nucleotide motifs (one to six nucleotides per motif) and are usually highly polymorphic due to a variable number of repeats. Insertions and deletions of repeat units are the result of DNA polymerase slippage that may occur during replication or unequal recombination $(7,9,24-26)$. Because of the species specificity and high sensitivity of SSRs, it is also possible to apply PCR analyses to contaminated DNA, i.e., DNA of $V$. inaequalis extracted directly from the lesion together with plant DNA. Since spores of one lesion are produced by one individual, the time-consuming procedure of producing and growing single-spore cultures would no longer be necessary (B. Koller, personal communication).

Several methods have been used for the development of microsatellite markers. SSR-containing sequences can be found by simply searching public sequence databases, e.g., GenBank. However, this is not possible for organisms not well studied or for which few sequences are published. On the other hand, genomic libraries can be constructed and screened for SSR-containing clones. This can be laborious and many colonies have to be screened, because the proportion of microsatellites to the entire genome is generally quite low (18). Examination of two published sequences of $\mathrm{V}$. inaequalis ( $\beta$-tubulin gene [M97951] and ribosomal DNA [U63624U63628]) revealed no SSR sequences. In Neurospora crassa the most frequent repeats are (AG) ${ }_{n}$ with $n \geq 4$ and (AAC) ${ }_{n}$ with $n \geq 3$ (6). We, thus, constructed genomic libraries of $V$. inaequalis en- 
riched for these two repeats. Once the cloned SSR sequence is determined, unique primer pairs can be designed from the SSR flanking region for the PCR amplification of the microsatellite locus.

To test the utility of the SSR markers, the 11 populations of $V$. inaequalis (350 isolates) collected in Europe in 1995 (30) have been tested with seven microsatellite markers. Nei's (15) expected genetic diversity for each marker, diversity within each population, and population differentiation were determined.

\section{MATERIALS AND METHODS}

Sampling, cultivation, and DNA extraction of $V$. inaequalis. Populations of $V$. inaequalis were collected in May and June 1995 at 11 sites in five European countries from trees chosen at random. One leaf with one lesion was sampled per tree. The origins of the populations were one from France ( $\mathrm{F}, 46$ lesions), two from Germany (D1, 28 lesions; and D2, 44 lesions), four from Italy (South Tyrol) (I1, 36 lesions; I2, 33 lesions; I3, 21 lesions; and I4, 31 lesions), one from the Netherlands (NL, 46 lesions), and three from Switzerland (CH1, 28 lesions; $\mathrm{CH} 2,14$ lesions; and $\mathrm{CH} 3,23$ lesions) (30). From each lesion, one single-spore isolate was produced (29). DNA was extracted as described in Tenzer and Gessler (29) or with the DNeasy Plant Mini Kit (Qiagen, Hilden, Germany).

Construction of enriched genomic libraries of $\mathrm{V}$. inaequalis and microsatellite sequence determination. One hundred micrograms of DNA of $V$. inaequalis was digested with the restriction enzyme Tsp509I (New England Biolabs, Inc., Mississauga, Canada). The fragments were separated on a $2 \%$ agarose gel in $1 \times$ Tris-borate-EDTA (TBE) buffer. The fraction containing fragments from 200 to 700 bp was recovered on a NA-45 DEAE cellulose membrane (Schleicher \& Schuell, Inc., Dassel, Germany) and ligated to adapters (TSPADSHORT, 5'-CGGAATTCTGGACTCAGTGCC-3'; and TSPADLONG, 5'-AATTGGCACTGAGTCCAGAATTCCG-3'). The size-selected fragments were then enriched separately for (TC) ${ }_{n}$ and (AAC) ${ }_{n}$ repeats through hybridization with the biotinylated oligonucleotides (TC) $)_{13}$ and (AAC) $)_{10}$ ligated to streptavidin-coated magnetic beads (Dynabeads M280; DYNAL, Oslo, Norway). Hybridization was performed in 10× SSC (1× SSC is $0.15 \mathrm{M} \mathrm{NaCl}$ plus $0.015 \mathrm{M}$ sodium citrate) and $0.2 \%$ sodium dodecyl sulfate (SDS) at $65^{\circ} \mathrm{C}$ for (TC) $)_{13}$ and $48^{\circ} \mathrm{C}$ for (AAC) $)_{10}$. Two stringent washing steps followed at $60^{\circ} \mathrm{C}$ in $2 \times \mathrm{SSC}$ and $0.1 \%$ SDS for (TC) $)_{13}$ and at $42^{\circ} \mathrm{C}$ in $0.5 \times \mathrm{SSC}$ and $0.1 \%$ SDS for $(\mathrm{AAC})_{10}$. Enriched fragments were amplified by PCR with TSPADSHORT as a primer and then restricted with EcoRI (Pharmacia Biotechnology, Inc., Uppsala, Sweden), purified with Wizard PCR Preps DNA purification system (Promega Corp., Madison, WI), and again size-selected for fragments of 200 to $700 \mathrm{bp}$. Following the manufacturer's instruction, the enriched fraction was cloned into the Lambda ZapII vector (Stratagene, Inc., La Jolla, CA). The Lambda ZapII library was screened by plaque lifting (400 PFU per plate) on nylon membranes (Hybond N; Amersham Pharmacia Biotech, Uppsala, Sweden) and hybridization to $\left(\gamma^{-33} \mathrm{P}\right)$ ATP $(1,000$ to 3,000 curie per mmol; Amersham Pharmacia Biotech) end-labeled $(\mathrm{TC})_{13}$ and (AAC) $)_{10}$, respectively. Hybridization was performed using $5 \times$ SSC, $1 \times$ blocking reagent (Boehringer $\mathrm{GmbH}$, Mannheim, Germany), $0.1 \%$ laurylsarcosine, and $0.02 \%$ SDS at $56^{\circ} \mathrm{C}$ for (TC) ${ }_{13}$ and $45^{\circ} \mathrm{C}$ for (AAC) ${ }_{10}$. Stringent washing steps followed in $0.5 \times \mathrm{SSC}$ and $0.1 \%$ SDS at $60^{\circ} \mathrm{C}$ for $(\mathrm{TC})_{13}$ and $45^{\circ} \mathrm{C}$ for (AAC) $)_{10}$. The plaques containing the SSRs could be identified following exposure of the membranes to X-ray films (X Omat AR; Kodak, Rochester, NY), and SSR-containing clones were retrieved from the agar plate. Insert size for each clone was determined with PCR using M13 universal primers, and in vivo excision of the pBluescript SK(-) phagemids with insert sizes between 200 and 700 bp was performed (Stratagene, Inc.). Plasmids were purified (Wizard Minipreps; Promega Corp.) and sequenced on an Applied Biosystems 373A automated sequencer (Applied Biosystems, Inc., Foster
City, CA) using the ABI PRISM dye terminator cycle sequencing kit or ALF (Pharmacia Biotechnology, Inc.). Oligonucleotide primer sequences for the PCR amplification of the microsatellite loci were designed using the program Primer (version 0.5; Whitehead Institute for Biomedical Research, Cambridge, MA). The theoretical melting temperature of the primers was chosen to be about $58^{\circ} \mathrm{C}$. Oligonucleotides were synthesized by MWG-Biotech (Ebersburg, Germany).

Microsatellite PCR amplification. PCR amplifications were performed in a 10- $\mu$ l volume containing $5 \mathrm{ng}$ of genomic DNA of $V$. inaequalis, $1 \times$ reaction buffer (Pharmacia Biotechnology, Inc.), $0.1 \mathrm{mM}$ of each dNTP, $0.2 \mu \mathrm{M}$ each of forward and reverse primers, and $1 \mathrm{U}$ of Taq polymerase (Pharmacia Biotechnology, Inc.). One quarter of the forward primer was end-labeled with $\left(\gamma^{33} \mathrm{P}\right)$ ATP (1,000 to 3,000 curie per mmol; Amersham Pharmacia Biotech). PCR was performed in a Gene Amp PCR System 9600 (Perkin Elmer, Foster City, CA) under the following conditions: 33 cycles of $40 \mathrm{~s}$ at $94^{\circ} \mathrm{C}, 40 \mathrm{~s}$ at $58^{\circ} \mathrm{C}$, and $20 \mathrm{~s}$ at $72^{\circ} \mathrm{C}$, with a final extension of $10 \mathrm{~min}$ at $72^{\circ} \mathrm{C}$. Before loading, the radio-labeled PCR products were denatured by adding 1 volume of denaturing gel loading buffer (23) and heating at $94^{\circ} \mathrm{C}$ for $5 \mathrm{~min}$. Microsatellite alleles were separated by running the reactions on a $6 \%$ denaturing acrylamide gel (National Diagnostic, Atlanta) in $1 \times \mathrm{TBE}$ buffer using an IBI DNA sequencing unit (STS45; Kodak/International Biotechnology Inc., New Haven, CT). After this run, gels were transferred onto Whatman $3 \mathrm{MM}$ paper (Whatman International, Ltd., Maidstone, England), dried at $80^{\circ} \mathrm{C}$ in a gel dryer (Bio-Rad Laboratories, Richmond, CA), and exposed for 24 to $48 \mathrm{~h}$ to an X-ray film (X Omat AR; Kodak).

Data analysis. The repeat type (perfect, imperfect, or compound) of each SSR marker was classified after Weber (32). The allele size of the isolate that was used for the construction of the library was determined by running the PCR product next to the PCR product of the plasmid with known length that was used for primer design. At the same locus, the allele sizes of the other alleles was determined by comparison with alleles of known length. Number of alleles and Nei's (15) expected genetic diversity $\left(\mathrm{H}_{\mathrm{E}}\right.$, equation 1) at each locus was determined. Genetic diversity within $\left(\mathrm{H}_{\mathrm{S}}\right.$, equation 2$)$ and among populations $\left(\mathrm{G}_{\mathrm{ST}}\right.$, equation 4$)$ was calculated with the following formulas (15)

$$
\begin{gathered}
\mathrm{H}_{\mathrm{E}}=1-\sum_{i=1}^{h} x_{i}^{2} \\
\mathrm{H}_{\mathrm{S}}=1-\sum_{i=1}^{h} x_{i j}^{2} \\
\mathrm{H}_{\mathrm{T}}=1-\sum_{i=1}^{k} \bar{x}_{i j}^{2} \\
\mathrm{G}_{\mathrm{ST}}=\frac{\mathrm{H}_{\mathrm{T}}-\overline{\mathrm{H}}_{\mathrm{S}}}{\mathrm{H}_{\mathrm{T}}}
\end{gathered}
$$

in which $h$ is the number of alleles, $x_{i}$ is the frequency of the $i$ th allele of each SSR marker, and $x_{i j}$ is the frequency of the $i$ th allele in population $j . \mathrm{H}_{\mathrm{T}}$ (equation 3 ) is the total genetic diversity over all populations, in which $k$ is the number of populations and $\bar{x}_{i j}$ is the frequency of allele $i$ averaged over all populations. $\overline{\mathrm{H}}_{\mathrm{S}}$ is the average genetic diversity of all populations.

\section{RESULTS}

Identification of microsatellite markers in $\mathbf{V}$. inaequalis. All of the 23 sequenced inserts contained one SSR. In some clones, the SSR was too close to the cloning site and primer design was not possible. Several primers that were designed for the amplification of the (TC) ${ }_{n}$-containing sequences did not amplify in a locusspecific manner and were, therefore, excluded from further analyses. Seven SSR markers were finally selected for use in the analyses 
of the $V$. inaequalis isolates (Fig. 1). Besides the microsatellite allele, which is indicated by an arrow in Figure 1, and 'shadow' bands, nonspecific PCR products were observed but were not considered in the analysis, since they are probably artifacts.
In general, loci with (TC) ${ }_{n}$ stretches were more polymorphic than loci with $(\mathrm{AAC})_{n}$ repeats with an average number of alleles of 30.3 and 3.8, respectively. We found four perfect repeat types, two imperfect repeats, and one compound repeat. Allele size range was large

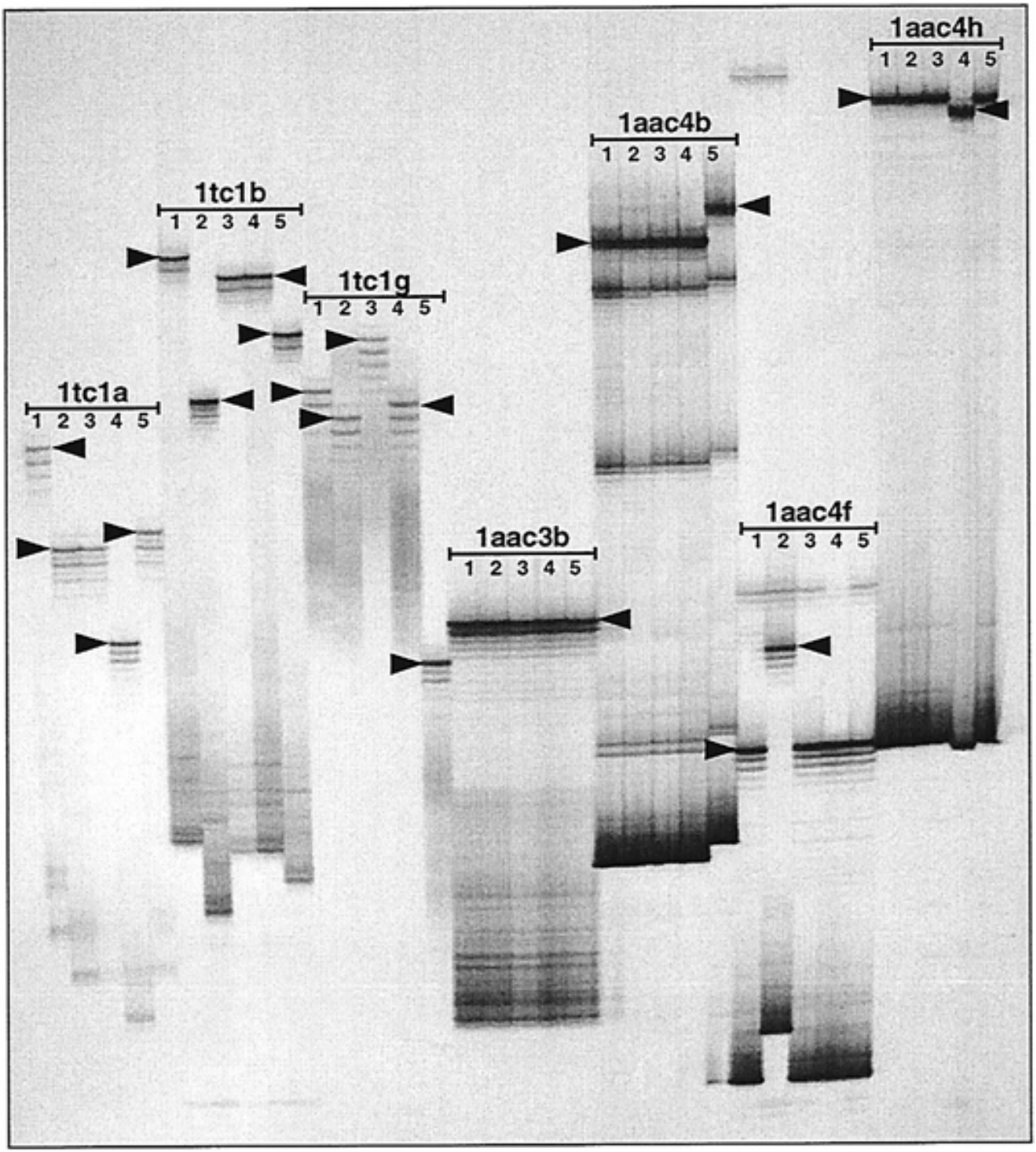

Fig. 1. Microsatellite analyses of five selected Venturia inaequalis isolates. Isolates 1 to 5 were tested with seven markers each (1tc1a, 1tc1b, $1 \mathrm{tc} 1 \mathrm{~g}, 1 \mathrm{aac} 3 \mathrm{~b}$, $1 \mathrm{aac} 4 \mathrm{~b}, 1 \mathrm{aac} 4 \mathrm{f}$, and 1aac4h). The alleles are indicated by arrows. Allele size of isolates 1 to 5 for locus $1 \mathrm{tc} 1 \mathrm{a}$ is $143,129,129,117$, and 131 bp; for locus $1 \mathrm{tc} 1 \mathrm{~b}$ is $173,153,169,169$, and $163 \mathrm{bp}$; for locus $1 \mathrm{tc} 1 \mathrm{~g}$ is $151,147,159,149$, and $116 \mathrm{bp}$; for locus $1 \mathrm{aac} 3 \mathrm{~b}$ is $121,121,121,121$, a nd $121 \mathrm{bp}$; for locus 1 aac4b is 171, 171, 171, 171, and $177 \mathrm{bp}$; for locus 1aac4f is 104, 115, 104, 104, and $104 \mathrm{bp}$; and for locus 1aac4h is 201, 201, 201, 198, and 201 bp.

TABLE 1. Microsatellite primer sequence, repeat type, allele size range, and number of alleles in the 11 populations of Venturia inaequalis collected in Europe in 1995

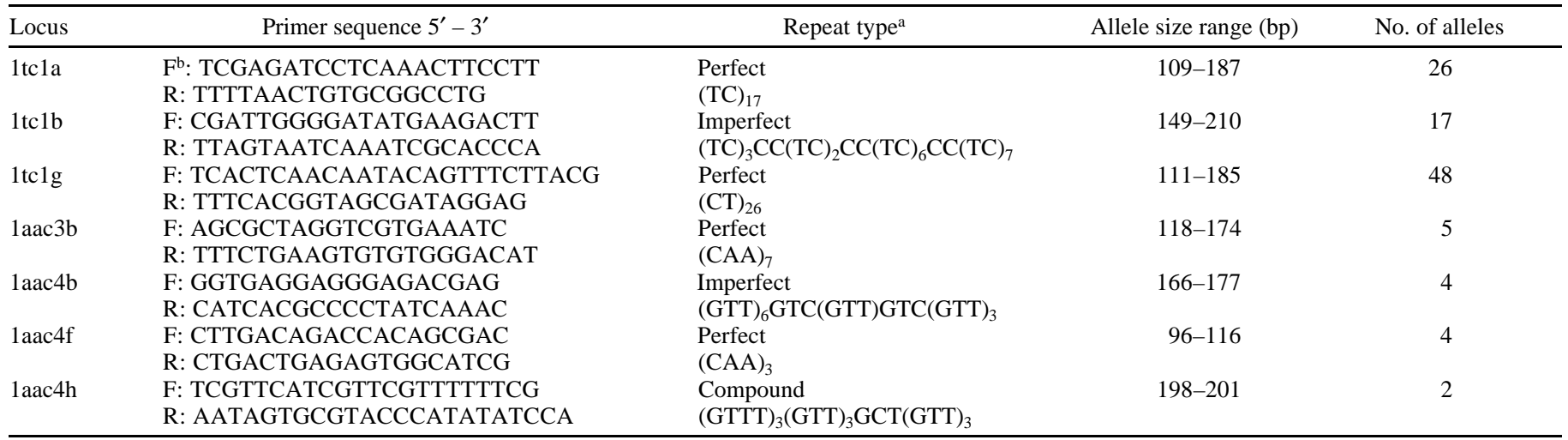

a After Weber (32).

${ }^{\mathrm{b}} \mathrm{F}=$ forward primer, and $\mathrm{R}=$ reverse primer. 
and differences did not always correspond to multiples of the repeat, possibly indicating more complex mutation events (Tables 1, 2 , and 3 ).

Genetic analyses of the $\boldsymbol{V}$. inaequalis populations. Only a few alleles were represented in every population, whereas all other alleles were found in only some populations (Tables 2 and 3). These so-called 'rare alleles' (27) appeared at very low frequencies. Several 'private alleles' (14), i.e., alleles only found in a single population, have been detected. Twenty-five isolates were found to have a private allele that was present only once. In two populations, the private allele was found in two isolates, and in one population, six isolates had the same private allele (Tables 2 and 3).

Average within-population diversity $\left(\mathrm{H}_{\mathrm{S}}\right)$ ranged from 0.28 to 0.49 and average expected genetic diversity $\left(\mathrm{H}_{\mathrm{E}}\right)$ was 0.46 . Differentiation among populations was low $\left(\mathrm{G}_{\mathrm{ST}}\right.$ ranging from 0.03 to 0.11 ) with an average of 0.07 (Table 4).

TABLE 2. Allele size and frequencies of the three microsatellite loci containing (TC $)_{n}$ repeats in Venturia inaequalis isolates collected in Europe in 1995

\begin{tabular}{|c|c|c|c|c|c|}
\hline \multicolumn{2}{|c|}{$1 \mathrm{tc} 1 \mathrm{a}(349)^{\mathrm{a}}$} & \multicolumn{2}{|c|}{$1 \mathrm{tc} 1 \mathrm{~b}(350)$} & \multicolumn{2}{|c|}{$1 \mathrm{tc} 1 \mathrm{~g}(259)$} \\
\hline Length (bp) & Frequency & Length (bp) & Frequency & Length (bp) & Frequency \\
\hline $109^{b}$ & $0.003^{b}$ & $149^{\mathrm{b}}$ & $0.003^{b}$ & $111^{\mathrm{b}}$ & $0.004^{\mathrm{b}}$ \\
\hline $111^{\mathrm{c}}$ & 0.115 & 153 & 0.071 & 116 & 0.027 \\
\hline 113 & 0.023 & $155^{\mathrm{b}}$ & $0.003^{\mathrm{b}}$ & 117 & 0.015 \\
\hline 115 & 0.052 & 157 & 0.006 & 118 & 0.012 \\
\hline 117 & 0.011 & $161^{\mathrm{b}}$ & $0.003^{\mathrm{b}}$ & $119^{\mathrm{b}}$ & $0.004^{b}$ \\
\hline $119^{\mathrm{b}}$ & $0.003^{\mathrm{b}}$ & 163 & 0.006 & 120 & 0.008 \\
\hline $121^{\mathrm{b}}$ & $0.006^{\mathrm{b}}$ & $167^{\mathrm{b}}$ & $0.003^{\mathrm{b}}$ & 121 & 0.008 \\
\hline 123 & 0.032 & $169^{d}$ & $0.666^{\mathrm{d}}$ & 122 & 0.015 \\
\hline 125 & 0.049 & $171^{\mathrm{d}}$ & $0.163^{\mathrm{d}}$ & 123 & 0.019 \\
\hline 127 & 0.043 & 173 & 0.023 & 124 & 0.039 \\
\hline $129^{d}$ & $0.258^{\mathrm{d}}$ & 177 & 0.006 & $125^{\mathrm{b}}$ & $0.004^{\mathrm{b}}$ \\
\hline $131^{\mathrm{d}}$ & $0.172^{\mathrm{d}}$ & $179^{b}$ & $0.003^{b}$ & 126 & 0.019 \\
\hline 133 & 0.095 & 181 & 0.023 & 127 & 0.035 \\
\hline 135 & 0.029 & $185^{\mathrm{b}}$ & $0.003^{b}$ & 128 & 0.008 \\
\hline 137 & 0.023 & $187^{b}$ & $0.003^{b}$ & 129 & 0.027 \\
\hline 139 & 0.011 & 189 & 0.014 & 130 & 0.027 \\
\hline 141 & 0.014 & $210^{\mathrm{b}}$ & $0.003^{\mathrm{b}}$ & 131 & 0.019 \\
\hline 143 & 0.014 & & & 132 & 0.058 \\
\hline $145^{\mathrm{b}}$ & $0.006^{\mathrm{b}}$ & & & 133 & 0.015 \\
\hline 147 & 0.006 & & & 134 & 0.012 \\
\hline 149 & 0.011 & & & $135^{\mathrm{d}}$ & $0.077^{\mathrm{d}}$ \\
\hline 151 & 0.006 & & & 137 & 0.058 \\
\hline 153 & 0.006 & & & 138 & 0.015 \\
\hline $155^{\mathrm{b}}$ & $0.003^{b}$ & & & 139 & 0.031 \\
\hline 177 & 0.009 & & & 141 & 0.039 \\
\hline $187^{\mathrm{b}}$ & $0.003^{\mathrm{b}}$ & & & 142 & 0.008 \\
\hline & & & & 143 & 0.035 \\
\hline & & & & 145 & 0.077 \\
\hline & & & & 147 & 0.035 \\
\hline & & & & 149 & 0.008 \\
\hline & & & & $150^{\mathrm{b}}$ & $0.004^{\mathrm{b}}$ \\
\hline & & & & 151 & 0.035 \\
\hline & & & & 153 & 0.050 \\
\hline & & & & $155^{\mathrm{b}}$ & $0.004^{\mathrm{b}}$ \\
\hline & & & & $156^{\mathrm{b}}$ & $0.004^{\mathrm{b}}$ \\
\hline & & & & 157 & 0.012 \\
\hline & & & & $158^{\mathrm{b}}$ & $0.004^{b}$ \\
\hline & & & & 159 & 0.039 \\
\hline & & & & 161 & 0.008 \\
\hline & & & & $162^{\mathrm{b}}$ & $0.004^{\mathrm{b}}$ \\
\hline & & & & 163 & 0.027 \\
\hline & & & & 165 & 0.012 \\
\hline & & & & 167 & 0.008 \\
\hline & & & & 169 & 0.012 \\
\hline & & & & $171^{\mathrm{b}}$ & $0.004^{b}$ \\
\hline & & & & 173 & 0.008 \\
\hline & & & & 175 & 0.008 \\
\hline & & & & $185^{\mathrm{b}}$ & $0.004^{\mathrm{b}}$ \\
\hline
\end{tabular}

\footnotetext{
a Sample size is indicated in parentheses.

b Private allele (the frequency of one individual is 0.003 , and at the locus $1 \mathrm{tc} 1 \mathrm{~g}$ is 0.004$)$.

c Rare allele (normal). All values without a superscript "b" or "d".

d Allele present in all populations.
}

\section{DISCUSSION}

Because polymerase slippage during replication of SSRs usually leads to insertions or deletions of one or two repeat units, the stepwise mutation model is generally accepted to explain the evolution of SSRs $(11,13,28,31)$. Based on this model, it is possible that alleles of the same size could have evolved independently from each other or that they are identical by descent. Thus, it is possible to find all alleles with differences in one repeat unit within the observed size range. However, in this study, only a fraction of all theoretically possible alleles were found. In the 350 isolates tested, one or two alleles were found at much higher frequencies at each locus. Thus, it is possible that the missing alleles appear at frequencies below the detection level or that they disappeared due to selection or genetic drift. It is also possible that some alleles had not yet evolved.

We expected only one amplicon, i.e., one allele, to amplify for each SSR locus, because $V$. inaequalis is haploid. However, at the locus $1 \mathrm{tc} 1 \mathrm{~g}$, we found 54 individuals out of $350(15 \%)$ that showed two amplicons. No other SSR locus showed more than one amplicon. Multilocus haplotypes based on the other six loci were compared for these 54 individuals. Based on the product of allele frequencies, we found that only 10 individuals with two amplicons at the locus $1 \mathrm{tc} 1 \mathrm{~g}$ could occur more than once by chance. This led us to speculate that the cultured fungus consisted of two individuals that only differ at the locus $1 \mathrm{tc} 1 \mathrm{~g}$. The possibility that the primer pair for $1 \mathrm{tc} 1 \mathrm{~g}$ could be used to amplify two homologous loci was excluded, because it is unlikely that $85 \%$ of the individuals that show only one amplicon have the same allele at both loci. This theory is supported by the finding that the frequency of individual alleles at the locus $1 \mathrm{tc} 1 \mathrm{~g}$ is very low. Mutations at the locus $1 \mathrm{tc} 1 \mathrm{~g}$ during cultivation of the fungus might have led to a culture containing two genotypes. It is probable that the two genotypes are present in the same proportion and, therefore, two amplicons are visible. This could be proven if samples were taken at different times after inoculation of the culture with fresh mycelium.

The advantages of microsatellite markers over the RAPD markers are their high specificity, high polymorphism, codominance, unambiguous scorability, and high reproducibility. Scoring of presence or absence of a RAPD band may be difficult, because the resolution on agarose gels is limited. Faint bands might not be detected due to poor staining, and bands differing by only a few base pairs are not differentiated. It is further impossible to detect contamination with extraneous DNA or with DNA from other isolates. The null allele at a RAPD locus is always scored as an allele even if sequence differences at or between primer binding sites are not the only cause of the lack of amplification. In fact, minor changes in the reaction conditions can also lead to an altered amplification, which in turn might cause misleading interpretation of the data. SSR null alleles were found sporadically in several populations, but they were very rare. Problems with amplification conditions and mutations in the primer-binding site are possible causes for nonamplification. Therefore, SSR null alleles in $V$. inaequalis

TABLE 3. Allele size and frequencies of the four microsatellite loci containing $(\mathrm{AAC})_{n}$ repeats in 350 Venturia inaequalis isolates collected in Europe in 1995

\begin{tabular}{|c|c|c|c|c|c|c|c|}
\hline \multicolumn{2}{|c|}{$1 \mathrm{aac} 3 \mathrm{~b}(348)^{\mathrm{a}}$} & \multicolumn{2}{|c|}{$1 \mathrm{aac} 4 \mathrm{~b}(348)$} & \multicolumn{2}{|c|}{$1 \mathrm{aac} 4 \mathrm{f}(350)$} & \multicolumn{2}{|c|}{ 1aac4h (348) } \\
\hline Length $^{b}$ & Frequency & Length & Frequency & Length & Frequency & Length & Frequency \\
\hline $118^{\mathrm{c}}$ & $0.017^{\mathrm{c}}$ & $166^{\mathrm{c}}$ & $0.003^{\mathrm{c}}$ & $95^{\mathrm{c}}$ & $0.003^{\mathrm{c}}$ & $198^{d}$ & $0.764^{\mathrm{d}}$ \\
\hline $121^{\mathrm{d}}$ & $0.848^{\mathrm{d}}$ & $171^{\mathrm{d}}$ & $0.954^{\mathrm{d}}$ & $104^{\mathrm{d}}$ & $0.943^{\mathrm{d}}$ & $201^{\mathrm{d}}$ & $0.236^{\mathrm{d}}$ \\
\hline $124^{\mathrm{e}}$ & 0.103 & 174 & 0.020 & 106 & 0.026 & & \\
\hline 126 & 0.029 & 177 & 0.023 & 115 & 0.029 & & \\
\hline $174^{\mathrm{c}}$ & $0.003^{\mathrm{c}}$ & & & & & & \\
\hline
\end{tabular}

a Sample size is indicated in parentheses.

b In base pairs.

c Private allele (the frequency of one individual is 0.003 ).

d Allele present in all populations.

e Rare allele (normal). All values without a superscript "b" or "c". 
TABLE 4. Within- $\left(\mathrm{H}_{\mathrm{S}}\right)$ and between- $\left(\mathrm{G}_{\mathrm{ST}}\right)$ population diversity, expected genetic diversity $\left(\mathrm{H}_{\mathrm{E}}\right)$ at each microsatellite locus, and average number of alleles of the 11 populations of Venturia inaequalis collected in Europe in 1995

\begin{tabular}{|c|c|c|c|c|c|c|c|c|c|c|c|c|c|}
\hline \multirow[b]{2}{*}{ Locus } & \multicolumn{11}{|c|}{$\mathrm{H}_{\mathrm{S}}$} & \multirow[b]{2}{*}{$\mathrm{H}_{\mathrm{E}}$} & \multirow[b]{2}{*}{$\mathrm{G}_{\mathrm{ST}}$} \\
\hline & $\mathrm{F}(44)^{\mathrm{a}}$ & D1 (28) & D2 (44) & I1 (36) & I2 (33) & I3 (21) & I4 (31) & NL (46) & CH1 (28) & $\mathrm{CH} 2(14)$ & CH3 (23) & & \\
\hline $1 \mathrm{tc} 1 \mathrm{a}$ & 0.78 & 0.42 & 0.72 & 0.87 & 0.90 & 0.90 & 0.86 & 0.77 & 0.86 & 0.78 & 0.73 & 0.87 & 0.11 \\
\hline $1 \mathrm{tc} 1 \mathrm{~b}$ & 0.60 & 0.14 & 0.52 & 0.56 & 0.48 & 0.67 & 0.47 & 0.54 & 0.55 & 0.37 & 0.47 & 0.52 & 0.05 \\
\hline $1 \mathrm{tc} 1 \mathrm{~g}$ & 0.94 & 0.74 & 0.92 & 0.93 & 0.93 & 0.91 & 0.91 & 0.94 & 0.87 & 0.86 & 0.85 & 0.96 & 0.07 \\
\hline $1 a a c 3 b$ & 0.24 & 0.00 & 0.20 & 0.36 & 0.22 & 0.32 & 0.27 & 0.16 & 0.56 & 0.13 & 0.38 & 0.27 & 0.07 \\
\hline $1 \mathrm{aac} 4 \mathrm{~b}$ & 0.08 & 0.35 & 0.00 & 0.11 & 0.06 & 0.00 & 0.00 & 0.09 & 0.07 & 0.00 & 0.16 & 0.09 & 0.08 \\
\hline $1 \mathrm{aac} 4 \mathrm{f}$ & 0.04 & 0.00 & 0.24 & 0.21 & 0.27 & 0.00 & 0.12 & 0.27 & 0.00 & 0.00 & 0.08 & 0.11 & 0.06 \\
\hline 1aac4h & 0.34 & 0.34 & 0.45 & 0.42 & 0.30 & 0.32 & 0.41 & 0.23 & 0.41 & 0.41 & 0.23 & 0.36 & 0.03 \\
\hline Average & 0.43 & 0.28 & 0.44 & 0.49 & 0.45 & 0.45 & 0.44 & 0.43 & 0.47 & 0.36 & 0.41 & 0.46 & 0.07 \\
\hline Average no. of alleles $b$ & 7.57 & 3.14 & 5.71 & 6.71 & 6.86 & 6.00 & 5.42 & 7.71 & 4.86 & 3.29 & 4.14 & & \\
\hline
\end{tabular}

a Sample size of the population is in parentheses. Populations were from France (F), Germany (D1 and D2), Italy (I1, I2, I3, and I4), the Netherlands (NL), and Switzerland (CH1, $\mathrm{CH} 2$, and $\mathrm{CH} 3)$.

${ }^{\mathrm{b}}$ Average number of alleles over all 11 populations is 15.14 .

are treated as missing data and the interpretation of the results will not be influenced by incorrect scoring.

We have shown that microsatellites are useful markers for the population genetics of $V$. inaequalis, even though the initial effort for the construction and screening of the enriched libraries was high. While diversity within the 11 European $V$. inaequalis populations collected in 1995 was very high, differentiation among them was low and many different shared rare alleles were found. However, it is not possible to determine whether alleles with the same length have evolved independently from each other or whether they are identical by descent and distributed by gene flow from one place to another. Which of the two possibilities is more probable is strongly dependent on the evolutionary history and the geographic distribution of the organism analyzed. Since apple trees and $V$. inaequalis were imported to Europe only 2,000 to 2,500 years ago by the Greeks and Romans from East Asia (10), it is most probable that shared rare alleles are a consequence of historical and current gene flow among the corresponding populations rather than the product of independent evolution.

The population from Ahrensburg (D1), where $V f$-virulent scab was first detected (in 1984) (19) and where 79\% of the samples were collected from varieties carrying the $V f$ gene, had the lowest within-population diversity as well as the smallest number of alleles. Furthermore, isolates from this population share only a few rare alleles with the other European populations, and private alleles could not be detected. These findings suggest that this population might have gone through an extreme bottleneck (16) that resulted in a reduction in genetic diversity and loss of alleles. The $V f$-virulent $V$. inaequalis population from Ahrensburg could have been founded by only one or a few pathotypes that were able to overcome the $V f$ resistance. Since only 11 years passed from the moment when $V f$ virulence was first detected in 1984 to when sampling was done in 1995, it is probable that this period of time may not be sufficient to restore the genetic diversity of the population.

It is not clear whether the $V f$-virulent founder population originated in Ahrensburg or whether, due to the importation of new Malus species as sources of scab resistance, it was introduced from Asia. However, selection favoring newly arising $V f$-virulent pathotypes that mutated from $V f$-avirulent individuals would be the same in each orchard where $V f$-resistant apple varieties are planted, but in most places the resistance is still effective. Therefore, we speculate that the $V f$-virulent pathotypes might have migrated from Asia to Ahrensburg and later to Kent and Wilheminadorp, most probably due to unintentional transport of infected plant material among these breeding stations.

\section{ACKNOWLEDGMENTS}

This work was supported by the Swiss Federal Office for Education and Science, Grant A6010, EU-Project AIR3-CT920473, and by the Swiss National Science Foundation, Grant 31-45062.95. We thank all partners of the EU-Project AIR3-CT920473 and friends that helped collect samples of Venturia inaequalis. We thank L. Gianfranceschi and A. Isler for critical reading of the manuscript.

\section{LITERATURE CITED}

1. Crosby, J. A., Janick, J., Pecknold, P. C., Korban, S. S., O'Connor, P. A., Ries, S. M., Goffreda, J., and Voordeckers, A. 1992. Breeding apples for scab resistance: 1945-1990. Fruit Var. J. 46:145-166.

2. Frey, C. N., and Keitt, G. W. 1925. Studies of spore dissemination of Venturia inaequalis in relation to seasonal development of apple scab. J. Agric. Res. 30:529-540.

3. Gessler, C. 1997. Disease resistance in plants: Examples of historical and current breeding and management strategies. Pages 153-178 in: Techniques for Reducing Pesticide Use. D. Pimentel, ed. John Wiley \& Sons Ltd., New York.

4. Gianfranceschi, L., Seglias, N., Tarchini, R., Komjanc, M., and Gessler, C. 1998. Simple sequence repeats for the genetic analysis of apple. Theor. Appl. Genet. 96:1069-1076.

5. Groppe, K., Sanders, I., Wiemken, A., and Boller, T. 1995. A microsatellite marker for studying the ecology and diversity of fungal endophytes (Epichloë spp.) in grasses. Appl. Environ. Microbiol. 61:3943-3949.

6. Hantula, J., Dusabenyagasani, M., and Hamelin, R. C. 1996. Random amplified microsatellites (RAMS)-A novel method for characterizing genetic variation within fungi. Eur. J. For. Pathol. 26:159-166.

7. Jeffreys, A. J., Royle, N. J., Wilson, V., and Wong, Z. 1988. Spontaneous mutation rates to new length alleles at tandem-repetitive hypervariable loci in human DNA. Nature 332:278-281.

8. Kemp, H., and Schouten, H. J. 1998. Gebrauchswert von Schorfresistenz (Vf) und resistenten Apfelsorten. Pages 220-231 in: Biologische Pflanzenschutzverfahren im Erwerbsobstbau. J. Kienzle and C. P. W. Zebitz, eds. Fachtagung Universität Hohenheim 9 und 10. März 1998.

9. Levinson, G., and Gutman, A. 1997. Slipped-strand mispairing: A major mechanism for DNA sequence evolution. Mol. Biol. Evol. 4:203-221.

10. MacHardy, W. E. 1996. Apple Scab: Biology, Epidemiology, and Management. The American Phytopathological Society, St. Paul, MN.

11. Michalakis, Y., and Excoffier, L. 1996. A generic estimation of population subdivision using distances between alleles with special reference for microsatellite loci. Genetics 142:1061-1064.

12. Morgante, M., and Olivieri, A. M. 1993. PCR-amplified microsatellites as markers in plant genetics. Plant J. 3:175-182.

13. Nauta, M. J., and Weissing, F. J. 1996. Constraints on allele size at microsatellite loci: Implications for genetic differentiation. Genetics 143: 1021-1032.

14. Neel, J. V. 1973. "Private" genetic variants and the frequency of mutation among South American Indians. Proc. Natl. Acad. Sci. U.S.A. 70: 3311-3315.

15. Nei, M. 1973. Analysis of gene diversity in subdivided populations. Proc. Natl. Acad. Sci. U.S.A. 70:3321-3323.

16. Nei, M., Maruyama, T., and Chakraborty, R. 1975. The bottleneck effect and genetic variability in populations. Evolution 29:1-10.

17. O'Connell, M., Danzmann, R. G., Cornuet, J. M., Wright, J. M., and Ferguson, M. M. 1997. Differentiation of rainbow trout (Oncorhynchus mykiss) populations in Lake Ontario and the evaluation of the stepwise mutation and infinite allele mutation models using microsatellite variability. Can. J. Fish. Aquat. Sci. 54:1391-1399.

18. Ostrander, E. A., Jong, P. M., Rine, J., and Duyk, G. 1992. Construction of small-insert genomic DNA libraries highly enriched for microsatellite repeat sequences. Proc. Natl. Acad. Sci. U.S.A. 89:3419-3423. 
19. Parisi, L., Lespinasse, Y., Guillaumes, J., and Krüger, J. 1993. A new race of Venturia inaequalis virulent to apples with resistance due to the Vf gene. Phytopathology 83:533-537.

20. Perez-Lezaun, A., Calafell, F., Mateu, E., Comas, D., Bosch, E., and Bertranpetit, J. 1997. Allele frequencies for 20 microsatellites in a worldwide population survey. Hum. Hered. 47:189-196.

21. Powell, W., Morgante, M., McDevitt, R., Vendramin, G. G., and Rafalski, J. A. 1995. Polymorphic simple sequence repeat regions in chloroplast genomes: Applications to the population genetics of pines. Proc. Natl. Acad. Sci. U.S.A. 92:7759-7763.

22. Roberts, A. L., and Crute, I. R. 1994. Apple scab resistance from Malus floribunda 821 ( Vf) is rendered ineffective by isolates of Venturia inaequalis from Malus floribunda. Norw. J. Agric. Sci. Suppl. 17:403406.

23. Sambrook, J., Fritsch, E. F., and Maniatis, T. 1989. Molecular Cloning: A Laboratory Manual. 2nd ed. Cold Spring Harbor Laboratory Press, Cold Spring Harbor, NY.

24. Schlötterer, C., and Tautz, D. 1992. Slippage synthesis of simple sequence DNA. Nucleic Acids Res. 20:211-215.

25. Sia, E. A., Jinks-Robertson, S., and Petes, T. D. 1997. Genetic control of microsatellite stability. Mutat. Res. 383:61-70.

26. Sia, E. A., Kokoska, R. J., Dominska, M., Greenwell, P., and Petes, T. D.
1997. Microsatellite instability in yeast: Dependence on repeat unit size and DNA mismatch repair genes. Mol. Cell. Biol. 17:2851-2858.

27. Slatkin, M. 1985. Gene flow in natural populations. Annu. Rev. Ecol. Syst. 16:393-430.

28. Slatkin, M. 1995. A measure of population subdivision based on microsatellite allele frequencies. Genetics 139:457-462.

29. Tenzer, I., and Gessler, C. 1997. Subdivision and genetic structure of four populations of Venturia inaequalis in Switzerland. Eur. J. Plant Pathol. 103:565-571.

30. Tenzer, I., and Gessler, C. Genetic diversity of Venturia inaequalis across Europe. Eur. J. Plant Pathol. In press.

31. Valdes, A. M., Slatkin, M., and Feimer, N. B. 1993. Allele frequencies at microsatellite loci: The stepwise mutation model revisited. Genetics 133: 737-749.

32. Weber, J. L. 1990. Informativeness of human $(\mathrm{dC}-\mathrm{dA})_{\mathrm{n}} \cdot(\mathrm{dG}-\mathrm{dT})_{\mathrm{n}}$ polymorphisms. Genomics 7:524-530.

33. Weber, J. L., and May, P. E. 1989. Abundant class of human DNA polymorphism which can be typed using the polymerase chain reaction. Am. J. Hum. Genet. 44:388-396.

34. Wiesmann, R. 1932. Ueberwinterung des Apfelschorfpilzes Fusicladium dendriticum im toten Blatt sowie die Ausbreitung der Sommersporen des Apfelschorfpilzes. Landwirtsch. Jahrb. Schweiz 46:616-679. 